\title{
A RHEXOXYLON-LIKE STEM FROM THE MORRISON FORMATION OF UTAH $^{1}$
}

\author{
Chester A. Arnold \\ Department of Botany, University of Michigan, Ann Arbor, Michigan
}

\section{A B S T R A C T}

\begin{abstract}
Arnold, Chester A. (U. Michigan, Ann Arbor.) A Rhexoxylon-like stem from the Morrison formation of Utah. Amer. Jour. Bot. 49(8): 883-886. Illus. 1962,- A silicified stem $11 \mathrm{ft}$ long from the Upper Jurassic of the Henry Mountains region of southern Utah resembles the South African and South American Upper Triassic genus Rhexoxylon, except for the absence of anomalously developed vascular tissue in the pith. It is described as Hermanophyton kirkbyorum gen. et sp. nov.
\end{abstract}

A sILICIFIED stem resembling Rhexoxylon was found several years ago in the canyon of Hansen Creek in Garfield County, Utah. Description of the stem was deferred, as it was expected that better-preserved specimens would subsequently be found. As yet, however, no others have been discovered, so in order to place the plant on record, the following description is given, based upon 2 pieces of the original and only known specimen.

The stem as found was $11 \mathrm{ft}$ long, and the 2 pieces are cross slices, one from near the base and the other farther along toward the tip. The length of the interval that separated the slices is unknown. The basal piece was given to the author by Prof. Lyman H. Daugherty, of San Jose, California, and the other by Mr. and Mrs. Sam Kirkby, of Riverside, California. The author's gratitude is hereby expressed to each of the 3 donors of the specimens. The pieces have been deposited in the Museum of Paleontology of the University of Michigan.

OccurRence-The stem was found about 2 miles south of the head of the Hansen Creek canyon and about 18 miles airline distance north of the junction of Hansen Creek with the Colorado River. Hansen Creek is in the southern part of the Henry Mountains region. From its source on the southwestern flank of Mount Hillers, the creek flows south over an area mostly covered by the Mancos shale. At the canyon head the stream descends steeply, first through the underlying Dakota sandstone, then into the Morrison formation. No sections have been measured near the canyon head, but in Thompson canyon, which joins the Hansen Creek canyon from the west about 5 miles downstream, the Morrison formation is about $650 \mathrm{ft}$ thick (Hunt, Averitt, and Miller, 1953). Two of its 3 members, the gray clay and the Salt Wash sandstone, are exposed there. The fossil stem is believed to have come from the Salt Wash sandstone member, which, according to Hunt and co-authors, contains an abundance of silicified tree trunks.

The Morrison formation is described as a heterogeneous mass of sediments suggestive of floodplain deposition. It is assigned to the Upper

1 Received for publication March 23, 1962.
Jurassic, though its topmost beds may at places transgress the Jurassic-Cretaceous boundary. The Morrison formation has long been known to contain plant fossils, and silicified cycadeoids and tree trunks of the Araucarioxylon type as much as $2 \mathrm{ft}$ in diameter have been seen along Hansen Creek and reported from other places.

Description-The stem, which was embedded in light-colored sandy shale (Fig. 1, 2) tapered gradually, and its surface was ornamented with about 13 coarse longitudinal ribs with crests 1.5 $3.0 \mathrm{~cm}$ apart. The basal piece used in this study is slightly more than $10 \mathrm{~cm}$ in diameter (Fig. 6) and the other is $6.6 \times 8.0 \mathrm{~cm}$ (Fig. 3). All tissues outside the wood had disappeared. The V-shaped grooves between the ribs were partly filled with hardened sandy material. In the smaller section these grooves extend inward to the pith and divide the wood into wedge-shaped sectors. Presumably these partitions were originally composed of parenchymatous tissue. In the basal section the sandy material extends only about halfway in, and toward the center the sectors are joined laterally by narrow bands of chalcedony.

The substance of the fossil is mostly lightcolored chalcedony that takes a high polish. The cellular structure of the mass can be detected at almost any place on a polished surface with the aid of a strong lens, but it stands out more distinctly in the darker-colored portions. No carbonaceous substances are visible in the cell walls which stand out from the cell cavities only because of the slightly lesser degree of transparency of the substance composing them. Thin sections are useless for microscopic study. The compound microscope could be used to a limited extent by fitting a vertical illuminator to a $16-$ or $8-\mathrm{mm}$ objective and examining radially and tangentially exposed fracture surfaces by reflected light. By careful manipulation small areas could be brought into reasonably sharp focus, and tracheary pitting and the rays could be seen. Photomicrographs with magnifications as high as $\times 120$ could be made (Fig. 5). Walton (1923) studied Rhexoxylon africanum by similar means, but because he had better-preserved material, was able to see more. 

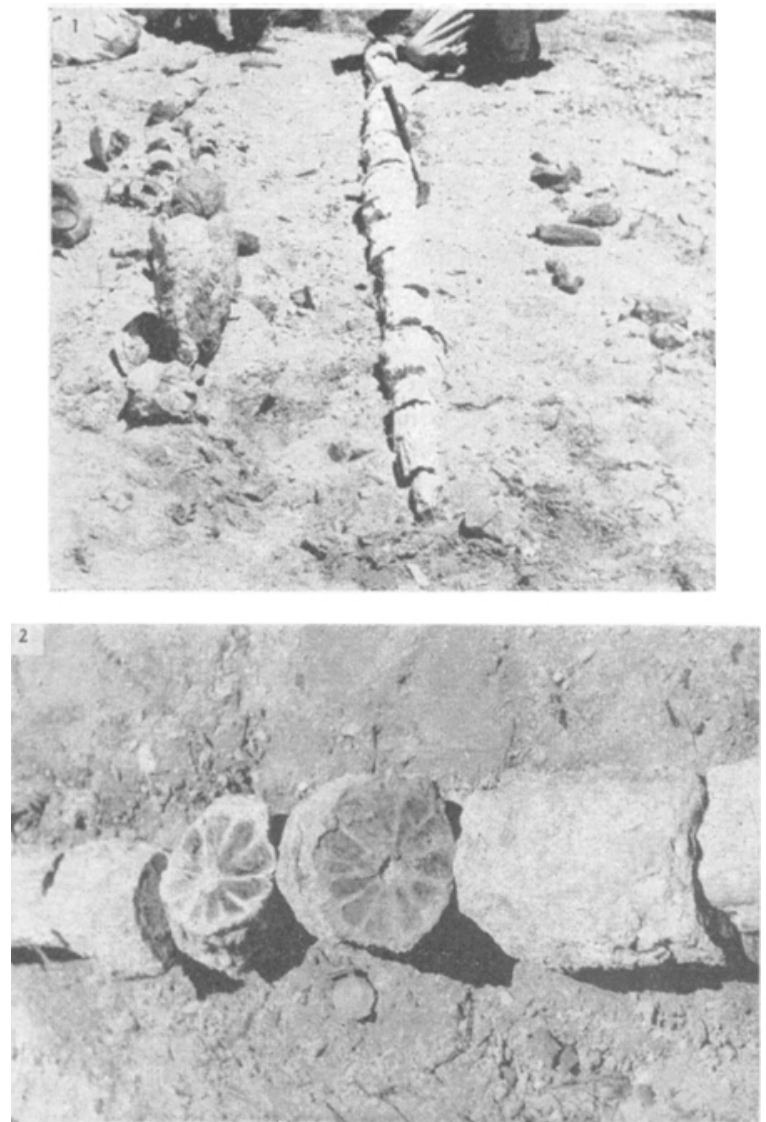

Fig. 1-2. Hermanophyton kirkbyorum, gen. et sp. nov.Fig. 1. Specimen before removal.-Fig. 2. Close-up of portions of 6 sections of the trunk.

In the piece from the base of the stem (Fig. 6) the pith occupies a space about $1 \mathrm{~cm}$ across, though no tissue is visible, and the contact between the pith and the surrounding wood is indistinct due to lack of differentiation between tissue and mineral matrix. In the section from higher in the stem (Fig. 3), the pith is about 2 $\mathrm{cm}$ wide and nearly circular, and the cavity left when the tissue broke down was filled with coarse rock fragments. The wood sectors are slightly truncated where they abut onto the pith. It appears that the pith was narrower low down in the stem than at higher levels.

The wood resembles that of a conifer in showing uniform texture and in being composed of thick-walled tracheids and narrow rays (Fig. 4). The tracheids are 25-40 $\mathrm{m} \mu$ in diameter and are regularly and evenly arranged in radially aligned rows. There are no resin ducts or secretory structures of any kind in the secondary wood to interfere with the orderly arrangement of the elements. No xylem parenchyma can be seen. The growth layers are $0.5 \mathrm{~mm}$ or less wide, and although they are distinctly visible in the better-preserved parts of the stem, the difference in cell size on opposite sides of adjacent layers is slight.
In cross section the tracheids are rectangular with minute intercellular spaces at the corners. The thick walls enclose round lumina which, in the best-preserved areas, are filled with white opaque material. The rays are almost as wide as the tracheids that flank them. They seldom exceed $0.5 \mathrm{~mm}$ in height, and nothing can be seen of their structure.

The pits appear to be restricted to the radial walls of the tracheids (Fig. 5). Those that have been observed are all in single rows. Some are rather distantly spaced and separated by intervals about equal to their diameters, while others are close together with their proximate sides slightly flattened. Occasional pits are in separated pairs. The more isolated pits are circular, and are $10-20 \mathrm{~m} \mu$ in diameter. The apcrtures, though difficult to see, appear to be round. Ray pitting has not been observed.

Rhexoxylon was first described by Bancroft (1913), but Walton (1923) has given the best account of it. He records it from the Beaufort and Stormberg series of Cape Colony, Natal, and Rhodesia. Recently he described and figured material from the Red Marls and Upper Sandstone of Nyasaland (Walton, 1956). Archangelsky and Brett (1961) have described a new species from the Ischigualasto formation of Argentina, which is the only authentic occurrence of Rhexoxylon outside of Africa. Concerning its reported occurrence in Antarctica (Walton, 1923), they point out that the material from there shows none of the essential characters of this genus and in some ways is different. Consequently they restore it to Antarcticoxylon where Seward originally placed it. All of these occurrences are believed to be within the Upper Triassic, and the genus is thus a component of the older part of the Upper Gondwana flora.

The Utah stem closely resembled Rhexoxylon, but the anomalously developed vascular tissue in the pith, which is an important generic character of that genus, is lacking. Whether its absence is due to incomplete preservation or whether it was never present is unknown. The latter is suggested by the rather sharply delimited pith cavity and the smooth inner surface of the wood which is shown interrupted only by the wide rays in the smaller specimen (Fig. 3). Had this stem been found anywhere in the Gondwana province, it would without doubt be identified as an incompletely preserved Rhexoxylon stem. However, in view of the lack of the Rhexoxylon type of anomalous vascular tissue in the pith of the Utah stem, and this coupled with the wide geographical and stratigraphic separation (a whole period), it seems undesirable to place it in the same genus with the Southern Hemisphere forms. Though one might muster reasons for suspecting generic identity on the basis of the pertinent evidence, the safest course seems to be to place the Utah stem in a different genus which is described as new. The name selected is in honor 

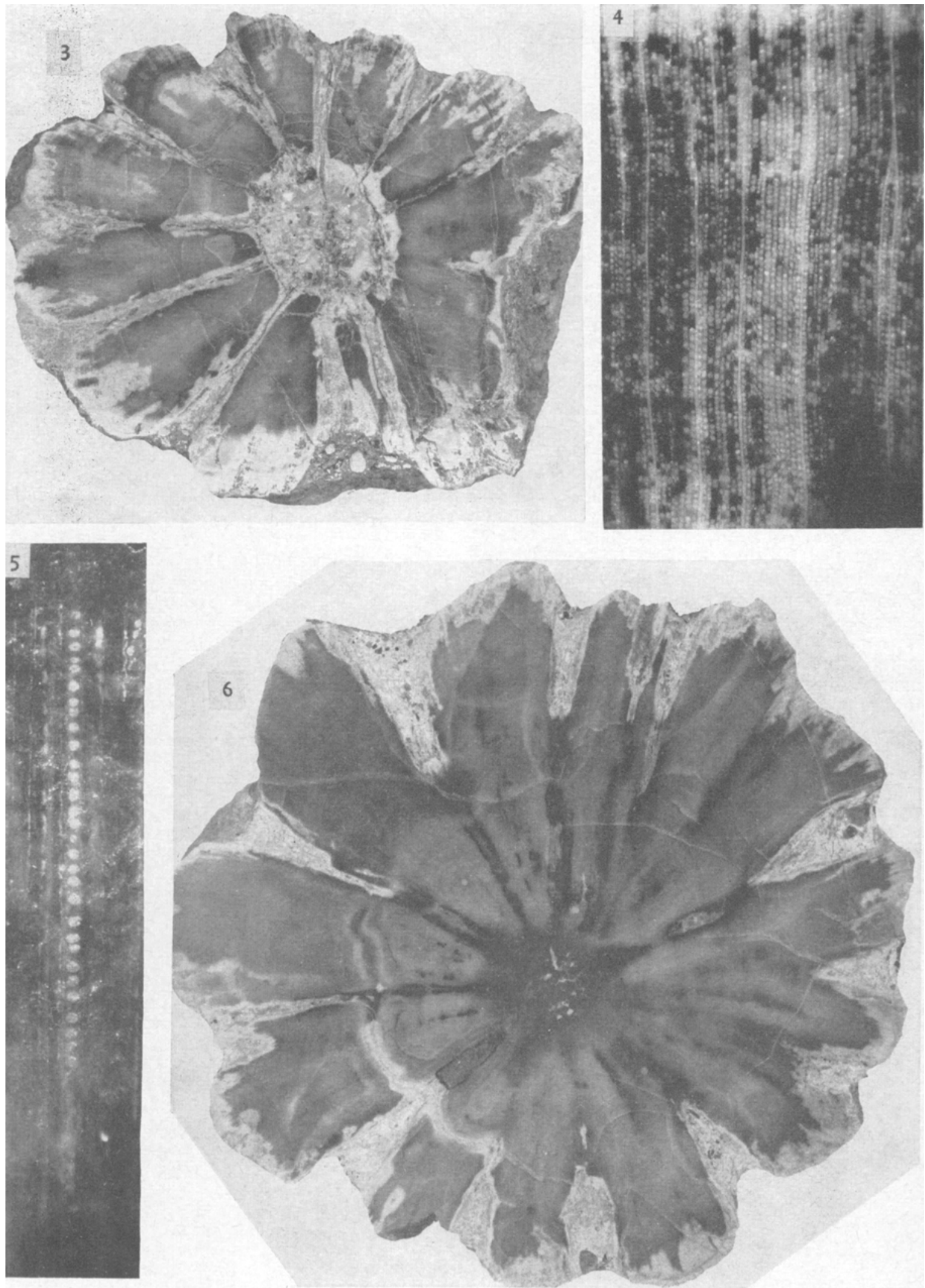

Fig. 3-6. Hermanophyton kirkbyorum. gen. et sp. nov.-Fig. 3. Section from near apex. Natural size.-Fig. 4. Photomicrograph of portion of surface of specimen shown in Fig. 3. $\times 25 .-$ Fig. 5. Photomicrograph of portion of radial plane showing row of pits in tracheid in secondary wood. $\times 120$. - Fig. 6 . Section taken from base of stem. Natural size. 
of Dr. Herman Becker, who took the photographs shown in Fig. 1, 2, and the species is named in recognition of Mr. and Mrs. Sam Kirkby who provided one of the specimens.

Hermanophyton kirkbyorum gen. et sp. nov.

Diagnosis Stems resembling Rhexoxylon but not showing anomalous vascular tissue in the pith region.

Horizon-Morrison formation, Upper Jurassic.

Locality-Hansen Creek canyon, Garfield County, Utah.

Holotype-UMMP No. 44451.

Occurring as it does in the Upper Triassic, Rhexoxylon is a component of the flora of the Upper Gondwana series which succeeds the Lower Gondwana series that bears the Glossopteris flora. Rhexoxylon therefore probably evolved from some ancestor in the Glossopteris flora. Hermanophyton, which appears later than Rhexoxylon, probably evolved during the time interval when the long migration from the Southern to the Northern Hemisphere was taking place. Since Rhexoxylon has recently been found in South America, the migration route was probably from there rather than from Africa.

Except for Bancroft, who thought Rhexoxylon was allied to the Medullosaceae, no morphologists have ventured to place this plant in any suprageneric category other than incertae sedis. In discussing possible affinities, authors have stressed its coniferous type of secondary wood and its general resemblance to certain angiospermous lianes. However, relationships with Coniferopsida that may be suggested by the wood structure seem to be effectively counterbalanced by grosser structures that are more in line with the Class Cycadopsida. A parallel instance is the Indian Jurassic genus Pentoxylon that also shows the pycnoxylic type of wood along with other characters that seem to favor affinity with the cycadopsid complex.

Archangelsky and Brett (1960) have proposed the order Rhexoxylales for Rhexoxylon. Though better-preserved and more complete material of Hermanophyton must be found before it can be adequately understood, it can be included in the Rhexoxylales and the ultimate inclusion in the class Cycadopsida would not come as a surprise. Relationships with the Paleozoic Medullosaceae are remote at best, but this does not exclude the possibility that the Rhexoxylales might have evolved at a remote date from medullosan stock, possibly as one offshoot among several, some of the others being the Cycadales, the Cycadeoidales, and the Pentoxylales.

In his discussion of the possibility that Rhexoxylon might have been a climbing plant, Walton mentions the lack of associated large trees which it might have climbed. Large trees are preserved in the Morrison formation, but the straight stem of Hermanophyton most likely stood upright and unsupported. The plant was probably a small tree intermediate in size between the large coniferophytes of the Jurassic period and the lowergrowing cycadeoids. All of these plants probably thrived in association on the more permanently established portions of the flood plains.

\section{LITERATURE CITED}

Archangelsky, S., and D. W. Bretrt. 1960. Nota preliminar sobre el hellazgo de Rhexoxylon en la cuenca de Ischigualasto limite de las Prov. San Juan y la Rioja. Acta Geol. Lilloana 3: 187-190.

- - AND - 1961. Studies on Triassic fossil plants of Argentina I. Rhexoxylon from the Ischigualasto formation. Phil. Trans. Roy. Soc. London, B, 244: 1-19.

BANCROFт, H. 1913. Rhexoxylon africanum, a new medullosan stem. Trans. Linn. Soc. London, B, Bot., 8: 159-168.

Hunt, C. B., P. Averite, And R. L. Mililer. 1953. Geology and geography of the Henry Mountains region, Utah. U. S. Geol. Surv. Prof. Pap. 228.

Walton, J. 1923. On Rhexoxylon, Bancroft-A Triassic genus of plants exhibiting a liane-type of vascular organization. Phil. Trans. Roy. Soc. London, B, 22: $79-109$.

1956. Rhexoxylon and Dadoxylon from the lower Shire region of Nyasaland and Portuguese East Africa. Colon. Geol. and Min. Res. (Nyasaland) 6: 159-168. 